\title{
Valorisation of food residues: waste to wealth using green chemical technologies
}

Rafael Luque ${ }^{1,2^{*}}$ and James H Clark ${ }^{3^{*}}$

\begin{abstract}
Waste valorisation practises have attracted a significant amount of attention in recent years with the aim of managing waste in the most sustainable way. Food waste constitutes a largely under-exploited residue from which a variety of valuable chemicals can be derived. This contribution is aimed to set the scene for a further development and promotion of sustainable food waste valorisation practises to different end products using green chemical technologies.
\end{abstract}

Keywords: Food waste, Green chemistry, Advanced valorisation strategies

Society faces a daunting future in terms of water, food and other resource scarcity. Recent studies have increasingly shown diminishing fossil fuel resources together with increasing waste generation which will get worse with a continued increase in population in future years. Addressing these challenges while not compromising the future of coming generations is not an easy task.

Waste is one of the most alarming problems the planet is currently experiencing and will surely have to address more effectively in the near future. Waste generation was reported to be over 2.25 billion tons in Western European Countries between 1998 and 2001 as well as 550 million tons in Eastern Europe Candidate Countries [1]. The main sources of this waste were construction (31\%), mining and quarrying (15\%) and most importantly agricultural and forestry waste which accounted for ca. $30 \%$ of the total generated waste. Food waste figures are also staggering: almost 90 million tonnes of food waste $(\mathrm{FW})$ are generated in the EU-27 each year, $42 \%$ of which came from the household sector [2]. Worldwide we throw away over 1 billion tons of edible food waste each year and the total for food supply chain waste ("from farm to fork") will be several billion. The carbon value of such volumes of organic matter is comparable to that in all of the chemicals and plastics we

\footnotetext{
*Correspondence: q62alsor@uco.es; james.clark@york.ac.uk

'Departamento de Química Orgánica, Universidad de Córdoba, Campus

Universitario de Rabanales, Edificio Marie Curie (C3), Córdoba E-14014, Spain ${ }^{3}$ Green Chemistry Centre of Excellence, The University of York, York YO10 $5 \mathrm{DD}, \mathrm{UK}$

Full list of author information is available at the end of the article
}

use every year in society but with the obvious advantage that it is renewable. Its exploitation will however, not be trivial. Most of domestic waste constitutes a significant logistical challenge and is under-utilised as a resource in spite of its potential as a source of valuable chemical compounds.

Waste valorisation is an attractive approach of increasing popularity which can offer a range of potentially useful alternatives for dealing with residues other than disposal and/or landfilling. Valorising food waste components could in fact lead to numerous possibilities for the production of valuable chemicals, fuels and products that society currently does not appreciate. Basic valorisation strategies including composting, recycling and burning (for energy recovery) are known and largely accepted practises worldwide which however, are able to recover/convert less than $50 \mathrm{wt} . \%$ of the waste into useful products [3,4]. Advanced valorisation strategies based on green chemical technologies are more appealing from both the practical, economic and sustainability viewpoints in that these can diversify the generation of multiple products from a single feedstock using environmentally sound technologies which combine bio/chemo-technological protocols. These include (but are not restricted to) microwave-assisted extraction of useful components, biological (e.g. fermentation) and combined chemo-enzymatic approaches for the production of useful bio-derived products, flow technologies able to provide cascade-type separation/isolation of valuable chemicals, etc. [3,4]. 
As key examples, citrus waste can be converted into chemicals such as limonene (a useful fragrance, solvent and chemical intermediate) and terpineols, materials and sources for animal feed notably proteins, pectin (a valuable material for food thickening) and sugars (which could be converted into bioethanol of other valuable compounds) using a simple and efficient microwave-assisted approach [5]. Biocollagenic materials with wound healing properties can be obtained from meat and leather waste via simple diluted acid extraction [6,7]. Waste bakery is converted into chemicals such as succinic acid or biodegradable polymers (e.g. polyhydroxybutyrate, PHB) by simply selecting adequate microbial strains in fermentation processes $[4,8]$ and higher alcohols including butanol, isobutanol and derivatives are produced from glucose and sugar-derived residues by using bioengineered Escherichia Coli bacteria [9]. Thermochemical processes (e.g. pyrolysis and in-situ upgrading) can also set the basis to a more sustainable production of biofuels and biosyngas from a range of food waste derived feedstocks $[10,11]$ and biodiesel has been reported to be produced from coffee waste grounds by simple methodologies $[12,13]$. Such advanced food waste valorisation practices are of increasing industrial interest as traditional feedstocks and chemicals derived therefrom become more scarce, expensive and environmentally unacceptable. Consumer pressure is also a powerful driver for change.

A range of case studies have recently become available (some of them previously highlighted in this contribution) for the conversion of FW-derived feedstocks into valuable products including bio-derived chemicals, biomaterials and biofuels [3-15] which illustrate the enormous future potential of advanced waste valorization strategies. For further information, authors are kindly referred to detailed overviews recently compiled by Lin et al. [3,4].

The combination of some of these and related processes (e.g. continuous flow biocatalysed production of esters from oil-derived waste streams) $[14,15]$ and their incorporation into similar future processes in biorefineries for local processing of feedstocks can pave the way to the biobased economy that the EU, US and other major trading blocks are striving for. This will also represent an important contribution towards sustainable development targets.

Despite these early promising studies much work needs to be done. A combined effort is needed from all different partners from legislative and other government agencies all the way to the leading food and user industries, with a particular emphasis on social awareness campaigns to challenge the traditional perception of waste as something that needs to be disposed of and without value. FW sources comprise a remarkable complexity as a consequence of their inherent diversity and variability but can provide an infinite number of possibilities and resources through designed and well thought out green technological valorization strategies. Maximum exploitation of the potential of FW will require contributions from a range of disciplines from engineering to (bio)chemistry, bio(techno)logy, environmental sciences, legislation and socio-economics. Together we can come up with the innovative technologies and approaches that can lead the way towards a more sustainable society based on a bio-economy.

\section{Competing interests}

The authors declare that they have no competing interests.

\section{Authors' contributions}

Both RL and JHC contributed to the writing of the manuscript, being RL main contributor of this work. Both authors read and approved the final manuscript.

\section{Acknowledgements}

Rafael Luque gratefully acknowledges support from the Spanish MICINN via the concession of a RyC contract (ref. RYC 2009-04199) and funding under projects P10-FQM-6711 (Consejeria de Ciencia e Innovacion, Junta de Andalucia) and CTQ2010-18126 and CTQ2011-28954-C02-02 (MICINN). R. Luque is also indebted to Prof. Guohua Chen, the Department of Chemical and Biomolecular Engineering (CBME) and HKUST for the provision of a visiting professorship as Distinguished Engineering Fellow. James Clark acknowledges funding under the ERDF programme for the food waste valorisation project "wastevalor". RL and JHC also gratefully acknowledge funding under COST TD1203 Action.

\section{Author details}

'Departamento de Química Orgánica, Universidad de Córdoba, Campus Universitario de Rabanales, Edificio Marie Curie (C3), Córdoba E-14014, Spain. 2Department of Chemical and Biomolecular Engineering (CBME), Hong Kong University of Science and Technology, Clear Water Bay, Kowloon, Hong Kong. ${ }^{3}$ Green Chemistry Centre of Excellence, The University of York, York YO10 5DD, UK

Received: 10 May 2013 Accepted: 18 June 2013

Published: 5 July 2013

\section{References}

1. Waste generated and treated in Europe: Luxembourg, Office for Official Publications of the European Communities. 2003. http://epp.eurostat.ec. europa.eu/cache/TY_OFFPUB/KS-55-03-471/EN/KS-55-03-471-EN.PDF.

2. B. I. Service: Preparatory Study on Food Waste across E.U.-27 for the European Commission. 2010:14. http://ec.europa.eu/environment/eussd/pdf/ bio_foodwaste_report.pdf, accessed 6 July 2012.

3. Lin CSK, Pfaltzgraff LA, Herrero-Davila L, Mubofu EB, Abderrahim S, Clark JH, Koutinas A, Kopsahelis N, Stamatelatou K, Dickson F, Thankappan S, Mohamed Z, Brocklesby R, Luque R: Food waste as a valuable resource for the production of chemicals, materials and fuels. Current situation and perspective. Energy Environ Sci 2013, 6:426-464.

4. Arancon RAD, Lin CSK, Chan KM, Kwan HT, Luque R: Advances on waste valorization strategies: news horizons for a more sustainable society. Energy Sci Eng 2013. doi:10.1002/ese3.9. in press.

5. Balu AM, Budarin $V$, Shuttleworth PS, Pfaltzgraff $L A$, Waldron $K$, Luque $R$, Clark JH: Valorisation of orange peel residues: waste to bio-chemicals and nanoporous materials. Chem Sus Chem 2012, 5:1694-1697.

6. Catalina M, Cot J, Balu AM, Serrano JC, Luque R: Tailor-made biopolymers from leather waste valorization. Green Chem 2012, 14:308-312.

7. Catalina M, Cot J, Borras M, De Lapuente J, Gonzalez J, Balu AM, Luque R: From waste to healing biopolymers: biomedical applicatons of biocollagen extracted from industrial residues in wound healing. Materials 2013, 6:1599-1607.

8. Zhang AY, Sun Z, Leung CCJ, Han W, Lau KY, Li M, Lin CSK: Valorisation of bakery waste for succinic acid production. Green Chem 2013, 15:690-695.

9. Atsumi S, Hanai T, Liao JC: Non-fermentative pathways for synthesis of branched-chain higher alcohols as biofuels. Nature 2008, 451:86-89. 
10. Luque R, Menendez JA, Arenillas A, Cot J: Microwave-assisted pyrolysis of biomass feedstocks: the way forward? Energy Environ Sci 2012, 5:5481-5548.

11. Bermudez JM, Francavilla M, Calvo EG, Arenillas A, Menéndez JA, Luque R: Efficient microwave-induced pyrolysis of macroalgae for hydrogen enriched biosyngas production. Energy Environ Sci 2013. submitted.

12. Kondamundi N, Mohapatra SK, Misra M: Spent coffee grounds as a versatile source of green energy. J Agric Food Chem 2008,

56:11757-11760

13. Calixto F, Fernandes J, Couto R, Hernández EJ, Najdanovic-Visak V, Simões PC: Synthesis of fatty acid methyl esters via direct transesterification with methanol/carbon dioxide mixtures from spent coffee grounds feedstock. Green Chem 2011, 13:1196-1202.

14. Junior II, Sutili FK, Gonçalves KM, Leal ICR, Miranda LSM, Ojeda M, Luque R, De Souza ROMA: Continuous flow valorization of fatty acid waste using silica-immobilized lipases. Green Chem 2013, 15:518-524.

15. Gonçalves KM, Sutili FK, Junior II, Flores MC, Miranda LSM, Leal ICR, Cordeiro Y, Luque R, De Souza ROMA: A comprehensive study on the activity and deactivation of immobilized Lecitase Ultra in esterifications of food waste streams to monoacylglycerols. Chem Sus Chem 2013, 6:872-879.

doi:10.1186/2043-7129-1-10

Cite this article as: Luque and Clark: Valorisation of food residues: waste to wealth using green chemical technologies. Sustainable Chemical

Processes 2013 1:10.

\section{Publish with ChemistryCentral and every scientist can read your work free of charge \\ "Open access provides opportunities to our colleagues in other parts of the globe, by allowing anyone to view the content free of charge." \\ W. Jeffery Hurst, The Hershey Company. \\ - available free of charge to the entire scientific community \\ - peer reviewed and published immediately upon acceptance \\ - cited in PubMed and archived on PubMed Central \\ - yours - you keep the copyright \\ Submit your manuscript here: \\ http://www.chemistrycentral.com/manuscript/<smiles>c1ccccc1</smiles> 